\title{
MATTER
}

\section{Vulnerable academic performances. Dialogue on matters of voice and silence in academia}

\author{
Monika Rogowska-Stangret \\ University of Warsaw \\ Polish-Japanese Academy of Information Technology
}

\section{Olga Cielemęcka}

University of Turku

Received: 19/11/2019

Accepted: 02/12/2019

DOI: https://doi.org/10.1344/jnmr.v1i1.30161

\section{Abstract}

In this dialogue, authors collectively reflect upon their experiences of being feminist philosophers. They diffract their personal and embodied experiences, philosophical reflections, and critiques of institutions in order to consider how and where a "vulnerable academic performance" is possible. In particular, the authors address matters of voice and silence within academia by asking the following questions: How are voices distributed and materialized in academia? Whose voice is heard and listened to vis-à-vis exisiting philosophical canons, classifications, and regimes of citationality? Bringing to the fore both personal and affective registers, the authors address the standards of legitimacy, hierarchies of voices and precarious labor conditions in academia as factors that render voices un/heard. With this in mind, they suggest a move towards vulnerability as a potent source of collective empowerment that is capable of disturbing academic power structures and canons.

\section{Keywords}

Vulnerability, neoliberal academia, feminism, academic practices, precariat 


\section{Financing}

Monika Rogowska-Stangret's contribution is funded by the grant from the Ministry of Science and Higher Education in Poland in the frames of the "National Programme for the Development of the Humanities" (2016-2019).

\section{Acknowledgments}

The authors would like to warmly thank the early readers of this article: Waltraud Ernst, Beatriz Revelles Benavente, Sam Skinner and Zoe, Maria Tamboukou and Iris van der Tuin for their generous and helpful feedback and for their continuous support.

This paper takes the shape of a dialogue - it is a continuation of a conversation that we have been engaged in for several years now as philosophers, feminists, untenured researchers and collaborators who are interested in questions of access and power in academic spaces, as well as in how such conditions directly impact our lives, bodies, hopes, ambitions, and dreams. We take up the topics of voice and silence to ask about standards of legitimacy and hierarchies of voices in academia and offer vulnerability as a device that can disturb them. We understand vulnerability to be a source of collective empowerment rather than a weakness. We weave together our personal and embodied experiences, philosophical reflections, and critiques of predominant institutions, philosophical canons, and classifications. Moreover, this ongoing project is a conversation amongst ourselves, yet it keeps an eye (and an ear) open to our readers and in the hopes of opening up this dialogue and inviting others to join. This is also why this dialogue has an open-ended structure; rather than summarizing the discussion we wish to establish an openness that allows for the diverse voices of academia to be heard. This dialogue does not have a closure; we would like to see it as an inspiration for debates about, within, against, and beyond academia.1 
In this conversation we diffract (Haraway, 1997; Barad, 2007) our voices through one another, letting the concepts that we think with, the ideas and experiences that we share amongst ourselves, and the vulnerabilities that we reveal to each other overlap like waves, creating new pathways for our dialogue(s). As such, diffraction is indeed "a lively affair" (Barad, 2014, p. 168) to us, a means of wondering and wandering about our own situatedness within, against, and beyond academia with the aim of "breathing new life into it" (Barad, 2014, p. 168). This approach is also a way to destabilize fossilized subject positions and to unsettle our own positions that we may take for granted, and, instead, search for collective-building strategies that emerge from our thinking about academic labour. As well, applying diffraction towards this line of inquiry effectively undermines the concept of vulnerability as a weakness 2 and, by making differences matter (Barad, 2007), it attends to patterns of relationality, solidarity, and possibilities, that emerge from encounters between variously situated and vulnerable subjects.

In this dialogue we mobilize an experimental mode of practicing thinking that involves both theorizing and feeling. We call it a "vulnerable academic performance," a method aimed at troubling traditional academic conventions, such as the rules dictating the format of scholarly articles or the stylistic expectations governing a conference presentation or lecture. We first presented this method at a New Materialist Politics and Economies of Knowledge conference in Maribor, Slovenia in 2015 (Rogowska-Stangret \& Cielemęcka,

2016; Maldonado \& Guenther, 2017) - so pervasive is this tendency that there is even a whole emergent literary genre of "quit lit" (see Schuman, 2013; Dunn, 2013). Taking into account our own precarious situatedness, the question of changing professional path has crossed our minds. However, there are multiple factors that influence this sort of decisions. That is why we recognize the need to think simultaneously within, against and beyond academia respectful of those who exit, those who stay, and those who are temporally in and temporally out. See also Nanna Hlín Halldórsdóttir's short essay Academic Praxiography in this volume. We thank Maria Tamboukou for bringing our attention to the phenomenon of quitting academia and pointing out some of the discussions held.

2 Other researchers have also undertaken this task of reconfiguring vulnerability, repurposing it towards political goals by use of various (interdisciplinary/transdisciplinary) methodological devices; see for example, the concept of weak resistance in Ewa Majewska's work (2018). 
2015), performing it in front of an academic audience well aware of the conventions and expectations already mentioned. With this move we hoped to offer a recalcitrant alternative to standardized academic performances by bringing the personal and the affective registers of scholarly presentation to the forefront of our talk. Herein, diffraction allows the meaning to arrive from within our conversing voices, from within our encounters - in the form of a response. 3 Vulnerability plays the essential role of a pre-condition to enter into a collective dialogue. It allows for an openness to that which emerges without us ever fully predicting or controling its trajectory, conditions reminiscent of Elizabeth Grosz's (2010) epistemological reflection on feminist theory as an always already openended project. Open-endedness is part and parcel of what we envision to be a performative, that is, an embodied, located, and relational dialogical practice. The range of meanings and uses of "performance" and "performativity" are both expansive and overwhelming to the point that parsing through their prolific application exceeds the scope of this piece. Yet we do evoke these terms to signal this conversation's strange position as both staged and spontaneous, curated and unconstrained, contained and open-ended. A vulnerable academic performance calls in the embodied, the experiential, the excitable, and the personal aspects of our existence and, consequently, disturbs, if only momentarily, the rigorous norms of speaking in academia. Furthermore, "vulnerable academic performance" is also a method of engaging with ourselves in academic life - within/in, against, and, we hope, a way of moving beyond academia defined as an institution of higher learning and research, foregrounding instead academia as a workplace and as a web of (power) relations that cuts across established institutions, canons, classifications, disciplines, rules, and hierarchies, involving both humans and non-humans as both subjects and objects. As such this method and this dialogue are a "power-sensitive

3 In our article "Stigmergy as a Collective Research Practice" (Cielemęcka \& RogowskaStangret, 2015) we further develop the importance of relationality, response-ability, com(mon)passion, collectivity, and experimenting for research practices today in advocating collective and collaborative approach to research. 
conversation" (Haraway, 1988, p. 590), particularly aware of the murmuring of power relations within and across academia.

\section{Olga Cielemęcka:}

“...the torment of getting up to speak. Her heart racing, at times entirely lost for words, ground and language slipping away - that's how daring a feat, how great a transgression it is for a woman to speak - even just open her mouth - in public..."

(Cixous, 1976, p. 880).

Have you ever felt this way?

Hélène Cixous's words have been with me, like a kind companion, for a long time. They helped me through my own doubts and difficulties as a feminist thinker and a woman in philosophy, while also pointing to a larger framework in which voices are either legitimized or silenced along the lines of class, gender expression, race, ethnicity, and ability, which designate the standards and expectations imposed on certain bodies within a simultaneously neoliberal and elitist institution.

I remember myself trying to speak; I would take a deep breath, I wanted to speak, I wanted to speak so badly, and I was just about to say something, but then no words would come out of my mouth. At other times, I would build up courage and speak up, and with this my own words would come back to me estranged, like an echo, as if they had just encountered some sort of an invisible obstacle from which they bounced back and came back to me: nude, vulnerable, deformed nobody responded to them.

In How to Do Things With Words (1962), the British philosopher of language John L. Austin described a special kind of sentence - he called them "performatives." Performatives are acts of speech that do not just describe the reality of the speaker but also actively change it - these utterances "do" things. However, Austin failed to recognize that words can likewise (trans)form bodies... the body reacts to them. Words hurt, and they continue to hurt for generations; 
they shape bodies, their histories, and their possibilities (see also Butler, 1997; Sedgwick, 2003). Herein, a feminist intervention was in order, and, sure enough, thinkers like Donna Haraway (1992) filled in the gaps left by Austin and his acolytes by pointing to an integral enmeshed reality in which the material, including the body, is affected by words - a so-called semiotic or discursive reality.

Monika, you have said that ours are "vulnerable academic performances". And you invite me to perform with you and to be vulnerable with you. What is this space of performance in academia? Where is it? "To perform" means to execute and to fulfill, but it also means to produce and to enliven. Performance encompasses re-creation, a certain repetition akin to sticking to a preordained script or scroll, but it is also a creation of something new; a staging as well as becoming. In this vulnerable performance I turn to you with an invitation to speak. I offer a space for you to speak within and from. But it is never completely safe for a woman (let alone other marginalized genders and bodies) to speak in the world of academia. To speak our bodies, to let the voice be heard comes with a risk; it is scary.

Monika Rogowska-Stangret: You began this conversation and, in this very gesture, you opened a space for your voice to be heard - that is a powerful moment. Just now, you invited me in by falling silent and changing registers towards listening rather than talking - that is when you performed a space for us to be heard. Very simple and very powerful at the same time. For me this is what academia should be about. I think that right now we are indeed performing academia as a space of dialogue: speaking up, thinking while talking, listening, keeping quiet - all done collectively, in collaboration, as a community-building practice. But the affects that are percolating through your voice also resonate with me. Risks are attached. These risks are connected to a variety of examples that illustrate the struggles of women and feminist researchers around censorship and sexual harassment, of being unheard, neglected, ridiculed, and of having one's career blocked or one's achievements unrecognized and attributed instead to 
male colleagues (known as the "Matilda effect"), of being gaslighted or criminalized.4

Academia is not usually a space of dialogue, of heterogeneous yet equal voices recognized, heard, listened to, and taken into consideration. Academia is a battlefield, it is not free of power relations - though it sometimes claims to be such under the guise of objectivity (which I will discuss below with reference to Donna Haraway), but quite on the contrary. It has its gatekeepers, who guard the territory, it has its strategies of survival, it has its successful and unsuccessful tactics, its stratagems, its clubs, its allies and its enemies. All covered over nicely with a promise of openness and objectivity. However, the promise of an objective point of view has been indicted and uncovered by Haraway in her boundarychallenging essay "Situated Knowledges: The Science Question in Feminism and the Privilege of Partial Perspective" (1988), wherein she exposes how scientists striving for objectivity perform what she terms the "god trick," a supposedly objective perspective from which one can observe and analyze phenomena. Objectivity is here understood to be a "view from above, from nowhere" (p. 589) or as a "[way] of being nowhere while claiming to see comprehensively" (p. 584); otherwise put, the "god trick" is being everywhere and nowhere in particular, yet still encompassing all points of view. Moreover, objectivity, as Haraway (p. 581) puts it, is

a conquering gaze from nowhere. This is the gaze that mythically inscribes all the marked bodies, that makes the unmarked category claim the power to see and not be seen, to represent while escaping representation. This gaze signifies the unmarked position of Man and White.

In this, objectivity erases the actual bodies, the specific material conditions, and the ingrained privileges of those engaged in the production of knowledge. At the

4 Number of scholars have put forward examples of their experiences as female-identified academics. See for example: Butler (2018), Romero-Hall, Aldemir, Colorado-Resa, DicksonDeane, Watson, and Sadaf (2018) (thank you to Sam Skinner for bringing our attention to this article), Ahmed (2017), Sullivan (2015), or Flood and Gill (2010). 
same time, the god trick helps to maintain a very particular power position under the guise of detachment and disembodiment.

As a response to a god trick that no longer does the trick of performing objective scientific inquiry, Haraway offers an alternative to prevailing notions of objective inquiry through her concepts of "situated knowledges" and "partial perspective" to assist in fomenting more accountable scientific research and knowledge production. Nonetheless, "situated knowledges" is rarely put to action in institutional settings. Trying to speak from one's own particular situatedness, from one's own embodied position always comes with the risk of being accused of propagating non-objective knowledge claims, of contaminating scientific methods with subjective or relative perspectives, of including accidental properties, and thus, of being unworthy of recognition and consideration. So, be aware when entering academia. It does not keep its promises. One may end up asking

why did you let me through the doors in the first place If you were just gonna turn around and force me out?

(Tagore, 2011, p. 37)5

I am wondering: was I ever invited to speak? Or, rather, was I directed to speak ("go, perform your academic self!"), which left me with nothing to say, with my silence, panic, and an urge - as I felt it - to disappear. This led me to thinking about the relationship between performance and certain spaces that you also mentioned - a space within me - do I have a space for my voice to be heard? Do I know my voice? - and outside of me - is it safe for me to speak? Does the academy - as an institution - provide a space for a feminist woman-philosopher to speak?

At a time we are facing misogynist movements growing in power across Europe, supported and spread by the increase of right-wing parties in governmental structures (for more on the subject see Kováts \& Põim, 2015; Kuhar \& Paternotte, 2017). Such political shifts have resulted in a failure to recognize gender studies

5 We would like to thank Whitney Stark for introducing us to Tagore's poem. 
as a worthy academic discipline, or, as is currently the case with CEU Central European University in Hungary (Petõ, 2018), the assumption of power by rightwing parties can lead to official policies that target existing, accreditated gender studies programs. What risks do I face? What are the frames of legitimacy? What topics are justified, what words, what ways of speaking? Would it be possible for me to fit in those frames? Or am I left aside? To paraphrase Luce Irigaray - when one asks me, "what am I thinking about?" I can only reply: Nothing. Everything (Irigaray, 1993 [1985], p. 29).

Female-identified (and others marginalized based on their bodies and gender expression) philosophers are dropping out - one by one - from academia, discontinuing their academic careers, facing being ridiculed on social media, and becoming objects of hate speech and censorship. How right was Michel Foucault (1972 [1971], pp. 228-229), when, in his inaugurating lecture at Collège de France on 2nd December 1970, he reckoned

[...] it seems to me, a certain fear hides behind this [...] apparent logophilia. It is as though these taboos, these barriers, thresholds and limits were deliberately dispossessed in order, at least partly, to master and control the great proliferation of discourse, in such a way as to relieve its richness of its most dangerous elements; to organize its disorder so as to skate around its most uncontrollable aspects. [...] There is undoubtedly in our society [...] a profound logophobia, a sort of dumb fear of these events, of this mass of spoken things, of everything that could possibly be violent, discontinuous, querulous, disordered even and perilous in it, of the incessant, disorderly buzzing of discourse.

The fear of a "disorderly buzzing of discourse" is indeed a powerful emotion that mobilizes various policing tools and forms the gatekeepers' actions in guarding an academic territory - not allowing for the buzzing to enter, silencing it with a more tolerable representation of such disordered buzzing. Such a buzzing might be connected to, among other things, a symbolic or representational feminine, or 
it may be identified with feminist practices that shape knowledge production today, for instance, the development of explicitly feminist approaches to science, physics, politics, or philosophy. Take as an example the image of a "reasonable feminist" - she is a figure produced by the guards that police academic territories in order to justify their existence and function: these guards point to the "reasonable feminist" in order to mark their own openness and tolerance towards difference. They say: "Hey! See, we accept feminists, but the ones who are being reasonable! These feminists are simply insane, hysterics, unsuited for academia!" In this way, institutional gatekeepers reformulate and repackage the problem: it is not about politics, it is only about those individuals who are simply too stupid - too disorderly - to enter our land of wisdom. That resembles how Judith Butler (1993, p. 44) commented on Plato's Timaeus: "[...] in authorizing a single representation of the feminine [here: a feminist], [Plato] means to prohibit the very proliferation of normative possibilities that the undesignatable might produce."

Fear of a disorderly buzzing of discourse often comes with a fear of different, confusing, or ill-defined bodies that need to be mastered and controled. We are, willy-nilly, left to perform in-between, if we are willing to (have strength to) perform at all. It struck me how dangerous but also exciting it is to perform in the space of borderlines (Anzaldúa, 1991). The "unruly edges" (Tsing, 2012) of such materialdiscursive academic performances make us both vulnerable and creative. The "unruly edges" of the cuts, where the proliferation, fermentation, gemmation take place are both painful and soothing, providing or opening up the space for more and more of us to perform.

OC: For many traditionally-oriented philosophers, particularly those that work in the analytical tradition, "feminist philosophy" is an illogical impossibility; it is, as you say, just a buzzing to their ears... I myself was trained in this tradition and thus very attached to a certain canon in which philosophical study necessarily means rational argumentation, rigorous rules for thinking, and established logics. And these characteristics have, seemingly, nothing to do with the body and its extensive needs 
and affectations, nor are they connected with the here and now of the many struggles for justice internal and external to academia proper. Needless to say, like many others, I oppose such an understanding of philosophy. If philosophy is not grounded in our stories, in the stories of our communities, in the solidarity networks that we build with each other, and in the specificity of our politics and ethics, then it is useless as a tool of interpreting, understanding and changing the world.

This brings me to a question of legitimacy: which discourses are permitted, legitimate, and legit, in academia? Who legitimizes them? What are the rules by which some arguments are listened to and even published, while others remain sin papeles in the world of contemporary academia? Who decides what, and on what grounds? In his essay "Critique of Violence" (1996), Walter Benjamin refutes this entire problem altogether. For Benjamin, legitimization is always based on violence - violence is both the source and the fundament of legitimization (see also Butler's (2012) exciting reading of this essay) - to which we could simply say: "Okay, boys - I'm done here; I refuse to take part in this game which you call philosophy, because I reject the rules by which you force me to play by." Or, following Donna Haraway (1988, p. 578), we could respond with: "They're just texts anyway, so let the boys have them back."

An alternative approach is to perform with and within, to position oneself against the rules of the game so as not to give up any ground, and, eventually, to manifest a challenge and change to these rules from within existing forms and practices. I believe we can extrapolate this strategy for academia generally but before we do so, we must acknowledge that the academic labor market is very difficult and unstable, and the working conditions within academic institutions are precarious and often exploitative. This, among other reasons, is why so many people quit some are forced to do so, some knowingly choose to leave a suboptimal working environment. Sometimes such decisions come with a feeling of loss (see Bartram, 2018) and other times exiting such conditions brings much needed relief. 
For a feminist philosopher to remain working within the field of academic philosophy means that she must commit herself to an abiding quest for spaces in which she can perform. You called these spaces - evoking Anzaldúa (1991) "borderlines." You write: "It struck me how dangerous and exciting it is to perform in the space of borderlines." Borderlines are the spaces of in-betweenness, which separate and delimit but, at the same time, remain indeterminate: unsettled, undecided, doubtful, and dangerous. And then, again, a "borderline" is also a type of personality disorder, one which is diagnosed mainly in women and associated with "hysterical" impulsivity, emotional instability, and sexual promiscuity. In our feminist archive, thinking with borderlines also evokes the work of feminists of color. For Anzaldúa, borderlands are the areas susceptible to la mezcla hybridity, zones similar to the borderlines that you describe as being unruly and rebellious, constituted through morphogenic edges where vulnerability goes hand in hand with creativity. Borderlines are thus prolific: cuts, wounds, and injuries disturb the homeostasis of the body surface and, simultaneously, they set in motion the processes of healing, re-growth, regeneration (of tissue), and formation (of a scar) in which bodily capabilities are mobilized.

However, having recognized the above, I need to stop here. There are cuts that will not heal and injuries which cannot be recovered from. Some damages are beyond repair, but only when we think of repair as an individualized process in which a sense of harm or loss is seen as unproductive and where change is unwelcomed.

Being silenced will not teach us how to speak. Just as being called "stupid" will not make us feel smart and confident. For this alchemical process in which vulnerability is transformed into empowerment to take place, it seems to me that yet another element is indispensable. The harm is not enough for the body to heal; rather, it is the mobilization of a collective effort of a body's cells that provides for such healing. In "The Phoenix, the Spider, and the Salamander," Catherine Malabou presents three different paradigms of recovery. The first one is represented by the figure of a phoenix: a mythological figure that is cyclically 
regenerated or reborn. "In the paradigm of phoenix," Malabou (2011, pp. 74-75) elaborates in Hegelian terms, "true regeneration is resurrection [...] to recover means 'to be present once again,' to return to the scene. Healing implies a reconstitution of wounded presence, an annulment of the defect, the mark, the lesion." It is in and through this first paradigm that the skin regenerates without leaving a scar.

The second paradigm is based on a figuration of a spider symbolizing deconstruction: "[...] the tissue, the web of the text are covered with marks, nicks, scratches that are so many scars of the impossibility of reconstituting the origin or taking on a new skin. These marks, however, do not show themselves and do not promise any vestige" (pp. 76-77). The third paradigm presented is that of a salamander - an animal which possesses auto-repairing, self-regenerating capabilities through which it can grow a new limb to replace the one surrendered. In this process, regeneration involves the shuffling around of cells at the wound site and the (re)assigning of a new specialization to them. What is fascinating in this particular model is the relation of the regenerative processes to the emergence of a scar. Malabou (2011, pp. 82-83) writes that

when a lizard's tail grows back, it leaves no trace of amputation at all. [...] The organ reconstitutes itself without scars, but this healing process does not raise life to a form of completion. The organ grows back different from the one it replaces - in size, weight, form. There is no scar, but there is difference. [...] Here "to recover" implies a finite survival [...], [t]he regrowth does not annul finitude, rather it is one of its expressions.

The paradigm of a salamander, just like the model of fermentation that you offered above, points to alchemical processes in which something entirely new emerges.

How, then, do we become more like salamanders with their endlessly regenerating tails? How can fermentative processes, which are in essence 
processes of breaking down and metamorphosis, foment something new and promising?

I think these questions are particularly timely now. In the era of \#MeToo, issues of voice and silence have taken center stage as we listen to and learn from the personal stories of being silenced and of speaking up against this silence. We also learn to recognize the systemic as well as the daily, "small" acts of violence that misogyny inflicts on bodies. This moment calls for a reorganization of the entire culture through a process of collective healing and regrowth.

MRS: I really enjoyed the example you provided from Malabou and how you challenged me with your questions. Being aware of my privileges and idiosyncrasies, I do not feel legitimized to speak using "we" in regard to vulnerability or in relation to the ways of coping with harms.

But, to go back to Malabou, I feel that we do not have any guarantees - we do not know for sure that our tails will regrow, that we will manage to create something anew, that we will be able to heal ourselves. The category of openness that I find so fascinating in this respect is only a promise, a condition that might enable "something new and promising to come to light," but it also may not yield anything productive at all. While openness raises hope, this - of course - may be jeopardized. Openness comes with risk - a very real one - of failing. Openness confirms and affirms the fact that we are not in the position to control - neither our bodies, nor our language. It is at this point where the autonomous, selfcontrolling, and self-centered subject turns out to be a pipe dream. To recognize and to admit this openness as the ground on which we are funded makes a difference in several ways that I will now address.

When I think of the policing practices I have experienced or encountered in academia, what strikes me is their self-referential character. These practices seem to be more like self-satisfied performances of hatred than akin to the open discussion they usually claim to be. They are closed in a vicious circle of hate, 
resentment, and defense via offense. It was a great relief when I realized that people who employed these practices were not talking about me, nor about any of us. In fact they were not discussing my projects, papers, academic performances at all - all they were doing was sharing their logophobia with others. In fact, the real object of those attacks are often fantasies about who is a woman-philosopher, a feminist-scientist, and how she may harm the status quo. Stating that does not mean that I am not aware of (or that I diminish) the fact that this "phantom war" may cost you your job. To silence us would - for the hegemonic power relations - mean to survive, to let us speak would entail castration, deprivation of voice, power, body. The logic of castration or deprivation implies that one is taking from me something I own, something that I feel is mine, my property. This logic is deprived of its infectious potential by the concept of the subject's openness - what is it that I own? What is it that I control? I would say only phantoms. Phantoms haunt us with a false claim of ownership. Phantoms that we created ourselves and overinvested with pain, refusing to let go of the harm and our narcissistic ego. Phantoms of the castrated phallus - was it ours to begin with? Please don't get me wrong, I don't mean to ignore anybody's pain, I just need to find a place for the joyfulness and play that comes with performance. And it is not even that... it is not only about making it possible for joy and playfulness to enter into my academic performances. It is much more and - at the same time - much less than that. The stakes are higher. It is about finding a place, where living an academic feminist life could be possible at all.

That's why I would reformulate your question: How do we then become salamanders whose tails regrow? I propose we ask instead: How do we detach ourselves from the lost tail, how do we get rid of the phantom of the lost tail, or at least how do we tame it - the phantom? Negotiate with it? How can we cherish and enjoy the regrown tail without being haunted by painful memories of what was lost? How can we separate ourselves from the feeling of loss, being a helpless and impotent victim so that we do not end up overwhelmed, blocked, unable to continue our work and life? 
I refer to Grosz again (1994, p. 73), who reckons that

the phantom is an expression of nostalgia for the unity and wholeness of the body, its completion. It is a memorial to the missing limb, a psychical delegate that stands in its place. [...] The phantom limb is the narcissistic reassertion of the limb's presence in the face of its manifest biological loss, an attempt to preserve the subject's narcissistic sense of bodily wholeness.

A phantom is also a condition of possibility for the replacement of the lost limb with a prosthesis (p. 71). Again, a vicious circle - the "I" demands a phantom out of misery and a longing for integrity, the phantom enables replacement and substitution. The logic of openness that I am arguing for here is the logic that resists narcissistic, self-sufficient subjectivity; it denies the possibility of replacement and it appreciates the opportunity to find new "tails" - new collective and individual solutions.

From this perspective it is always about breaking the vicious circle of loss-nostalgiareplacement. "Given the choice between conformity to the limitative demands of adaptation and death, it [instinct - MRS] invents a third way: the excess invention of a more to life. An inventiveness immanent to the topology of experience, one with its lived qualities, at its most subjective leading edge, spontaneously responds to adaptive pressures" (Massumi, 2014, p. 18). How might we - individually and collectively - invent third ways that are simultaneously with/in and against academia?

And again the borderlines are to be addressed urgently. The power of the phantom remains a constant "memory irritation" - we cannot forget about our losses, that's why we feel impotent. According to Rosi Braidotti (2008, p. 22) this is the really negative effect of negative affects - blockages. This is the state where one forgets about "an inventiveness immanent to the topology of experience" (Massumi, 2014, p.18). How much can I bear? What are my limits of harm? I don't know, it is yet to be performed. You said: "Being silenced won't teach us how to speak. Just as being called 'stupid' won't make us feel smart," and this is true. But these postulates may reveal some of our limits: can we stand the pain and not fall apart? How do we 
perform while being "out of joint"? Can "third ways" be born out of this state of "outof-jointness" without - however - sanctifying, sublimating, or idealizing pain and vulnerability? But instead recognizing the conditions of precarious knowledge production - in regards to both limits and potentialities - and putting into action vulnerable academic performances and collective becomings that destabilize wellestablished canons and traditional classifications.

This leads me to an appreciation of Foucault's preoccupation with care for the self (1988 [1984]), considered in conjunction with Judith Butler's question: "Under what conditions does self-poiesis become a relational category?" (2013, p. 67). Vulnerable academic performances are - to my mind - precisely about being "out of joint," about being in the borderlines or spaces of in-betweenness, as you dubbed them, and they are also about performing the self as a relation with others, escaping the false choice between adaptation and death, conformity and resignation.

All this having been said, I wish to direct our attention again to matters of voice and silence in academia. And I ask: how to speak, listen, and keep quiet in academia? How to survive with/in/against or even beyond academia proper through performing vulnerably? How to produce knowledge in precarious times? How to bring collectives together?

OC: "Time is out of joint" is a quote from Shakespeare's Hamlet with which Jacques Derrida was quite fascinated. I believe we are witnessing a moment in which things are stirring and buzzing, and I would like to hope that these are moments of dislocating and of throwing the old patriarchal order out of joint. Past injustices are brought up to light, calling out the misogynist foundations of our institutions, our intimacies, and our everyday interactions. While the \#MeToo movement gains momentum as more survivors of sexual harassment and violence speak out, it carries a promise of a change. Audre Lorde (1984, p. 41) famously wrote

My silences had not protected me. Your silence will not protect you. But for every real word spoken, for every attempt I had ever made to speak those truths for which I am still seeking, I had made contact 
with other women while we examined the words to fit a world in which we all believed, bridging our differences.

The politics of voice and silence are gendered - as much as they are raced and classed. Audre Lorde wrote about this extensively in reference to violence against Black and queer women. But by "voice" here I don't only mean its discursive register, but also the very materiality of voice - things like vocal timbre and height ("does it sound 'masculine' or 'feminine'?") or a voice's fluidity and accent ("does it sound 'native' or 'foreign'?") (see also Cielemęcka, 2017). Speech pathologist David Azul brings our attention to this aspect of speaking when writing about the materiality of trans and gender diverse voices and the voice-lessness that is imposed on them by the violence of gender dichotomy. Azul predicts that one day "in the foreseeable future, $[. .$.$] we will be able to 3D print standard-sized male or female voice organs$ and implant them into suitable pharyngo-laryngectomized throats in a simple organ replacement procedure" (Azul, 2018, p. 130). However, instead of cherishing this possible transhuman future, Azul celebrates the hums of difference, the nonconforming vibrations and richness of multiple, variously gendered voices.

I believe that the momentum generated by \#MeToo allows us to recognize that the question of silencing and speaking goes much deeper and reaches beyond the specific problems of sexual harassment. It calls for a systemic critique of these frameworks - misogyny, racism, classism, cis-hetero-normativity, ableism - that legitimize some voices and not others. The same frameworks are entrenched in academia, actively regulating knowledge production. Let me one more time refer to Shaunga Tagore's poem "A Slam on Feminism in Academia." Tagore pulls no punches when exposing academic feminism as more often than not giving voice to the white, privileged, "able-bodied and -minded enough/ to be given luxury of enjoying sitting in a corner reading 900 pages a week" (2011, p. 39).

So what are we to do? I would like to turn to Sara Ahmed (2017, pp. 260-261) to guide us here:

Even if speaking out is not possible, it is necessary. [...] But feminist speech can take many forms. We become more inventive with 
forms the harder it is to get through. Speaking out and speaking with, sheltering those who speak; these acts of spreading the word, are world making.

MRS: Speaking or voicing ideas, thoughts, and intuitions, engaging in dialogues like the one we perform here - is indeed world making. It accomplishes this in the sense that we - as feminist philosophers - often lack institutional support and are unable to enter or perform in spaces provided for philosophical thinking and related practices. We need to make a stage for our vulnerable academic performances. Akin to birds of paradise or bowerbirds that set themselves a stage on which to perform and attract a mate, we need to build our own stages, our own "bowers," and our own academic spaces in order to provide for ourselves the conditions of possibility for feminist research to happen, to be voiced and to be heard. These stages are built for ourselves, for other women-identified-philosophers, for feminist researchers, as well as for scholars of marginalized genders and bodies. They should be built and supported collectively in hopes that others, too, will feel welcomed to perform on them. Importantly, the process of preparing the grounds for such performances must be recognized as work, as labor that consumes time, energy, and emotional, social, and cultural resources.

In describing the formation of a new social class, namely the precariat, Guy Standing addresses a phenomenon dubbed "work-for-labor" (2011, pp. 120-121), which involves "filling in forms, queuing, commuting to employment exchanges, commuting in search of jobs, commuting to job training and so on" (2011, p. 48). Building a stage for ourselves in academia is even more than "work-for-labor;" needeless to say, academia as a work environment is becoming more and more precarious, and with its reliance on adjunct and contract-based teaching labor, the academic work force feeds directly into the ever enlarging precariat. 6 This is what is needed for one to labor - the stamina that it takes to be capable of doing it day after day, one rejection

6 Standing recognizes how academic work environment changes and how education is commodified (see 2011, pp. 67-72). A number of references mentions precarity as depicting conditions of academic work in neoliberalism. In feminist context see for example Taylor \& Lahad, 2018. 
after another, of surviving being the object of hate speech or ridicule one time after another. It takes time, as well as emotional and collective energy and endurance, but it also invites creativity and resourcefulness in order to find the ways that these stages can be built. This is what elsewhere I called "politics of squatting" and in this context I would call us "squatters of academia." Squatting here is a metaphor and a practice "useful to grasp the mechanism of creating and producing the time and space for the new" (Rogowska-Stangret, 2015, p. 66). In the "politics of squatting" it is also crucial to uncover the previous and existing efforts taken to build spaces for (vulnerable) performances, to reveal the process required for one to get to the position of speaking, exposing the conditions of im/possibility of using one's own voice.

Above you mentioned an essay by Catherine Malabou depicting three models of recovery. The first one was a phoenix - a figure that represents regeneration that does not leave a scar. In many ways throughout academic life this ideal prevails. The time, energy, and emotional work put to work for academic purposes is erased or subsumed - only the final outcome and bottomline matters. In other words, the scar of unrecognized work is there, only invisibilized. As Malou Juelskjær and RogowskaStangret put it:

All the hard work that went into enabling "results" (grant applications, experiments, data production and analysis, developing and dismissing theories, consulting with colleagues, engaging with other researchers' results, and so forth) is made invisible, "at the end of the day or project, the product of the physicists' activity is freed from any marks of this work" (Schrader, 2012, p. 119). These mechanisms do not apply solely to physicists, but resonate with, and might be also used to investigate, products of the work of researchers in other academic disciplines. (Juelskjær \& RogowskaStangret, 2017, p. 3)

A phoenix in this respect is a fake that invisibilizes the work that is put to work, the efforts put towards living a feminist academic life, and the conditions that make feminist research im/possible. Scars should not be erased but rather revealed and 
appreciated. They are materialized signs of what it takes to endure. You opened our conversation with a quote from Cixous about "the torment of getting up to speak" (Cixous, 1976, p. 880). This torment materializes also in our voices: trembling, of different timbre, accent, stammering, too quiet or too loud, considered to be too polite or too aggressive, too slow or too quick, sometimes estranged or alienated, out-ofjoint, sometimes intimate and revealing so much of the struggles of (and it is worth repeating) "...the torment of getting up to speak" (Cixous, 1976, p. 880). Those vulnerable voices of ours are also and at once our stages, our academic performances, and our scars. Do not hide them succumbing to an illusion offered by a phoenix. Because the scars, the scarred and vulnerable voices do matter and they are woven into how academia today sounds. Just listen to the borderlines, the spaces in-between, the "unruly edges." 


\section{Bibliography}

Ahmed, Sara (2017). Living a feminist life. Durham and London: Duke University Press.

Ahmed, Sara (2016, August 27). Resignation is a feminist issue [Blog post].

Retrieved from https://feministkilljoys.com/2016/08/27/resignation-is-a-feministissue/.

Anzaldúa, Gloria (1991). Borderlands: The new Mestiza/ la frontera. San Francisco: Aunt Lute Books.

Austin, John, Langshaw (1962). How to do things with words. Oxford: Clarendon Press.

Azul, David (2018). Trans speaking voice-lessness: A fictocritical essay. Graduate Journal of Social Science, 14(2), 107-134. Retrieved from http://gjss.org/sites/default/files/issues/chapters/papers/GJSS\%20Vol\%20142\%207\%20Azul.pdf.

Barad, Karen (2014). Diffracting diffraction: Cutting together-apart. Parallax 20, 168-187.

Barad, Karen (2007). Meeting the universe halfway: Quantum physics and the entanglement of matter and meaning. Durham and London: Duke University Press.

Bartram, Erin (2018, February 11). The sublimated grief of the left behind. Erin Bartram [Blog post]. Retrieved from http://erinbartram.com/uncategorized/thesublimated-grief-of-the-left-behind/.

Benjamin, Walter (1996). Critique of violence. Selected writings; Volume 1; 1913-1926. London: The Belknap Press of Harvard University Press.

Braidotti, Rosi (2008). Affirmation, pain and empowerment. Asian Journal of Women's Studies, 14(3), 7-36. Retrieved from https://www.tandfonline.com/doi/abs/10.1080/12259276.2008.11666049. 
Butler, Judith (2018, May 27). The criminalization of knowledge: Why the struggle for academic freedom is the struggle for democracy. The Chronicle of Higher Education. Retrieved from https://www.chronicle.com/article/TheCriminalization-of/243501.

Butler, Judith \& Athanasiou, Athena (2013). Dispossession: The performative in the political. Cambridge: Polity Press.

Butler, Judith (1993). Bodies that matter: On the discursive limits of "sex." New York and London: Routledge.

Butler, Judith (2012). Walter Benjamin and the Critique of Violence. In J. Butler, Parting ways: Jewishness and the critique of Zionism (pp. 69-98). New York: Columbia University Press.

Butler, Judith (1997). Excitable speech: A politics of the performative. New York and London: Routledge.

Cielemęcka, Olga (2017). "Let the thinking breathe." Corporeal-thinking in classroom settings. In E. Just \& W. Grahn (Eds.), Theories of affect and concepts in generic skills education: Adventurous encounters (pp. 151-170). Newcastle: Cambridge Scholars Publishing.

Cielemęcka, Olga \& Rogowska-Stangret, Monika (2015). Stigmergy as a collective research practice. In I. Ackermann, K. Chruszczewska, E. R. Janion, Á. Máté, \& N. Obukowicz (Eds.), Imagine there were no humanities... Transdisciplinary perspectives (pp. 51-58). Warsaw: Wydawnictwo DiG. Cixous, Helene. (1976). The laugh of the Medusa. (K. Cohen \& P. Cohen, Trans.). Signs 1(4), 875-893.

Dunn, Sydni (2013, December 12). Why so many academics quit and tell. Chronicle Vitae. Retrieved from https://chroniclevitae.com/news/216-why-somany-academics-quit-and-tell.

Flood, Roisin \& Gill, Rosalind (Eds.). (2010). Secrecy and silence in the research process: Feminist reflections. London: Routledge. 
Foucault, Michel (1988 [1984]). The history of sexuality, Vol. 3: The care of the self. (R. Hurley, Trans.). New York: Vintage Books.

Foucault, Michel (1972 [1971]). The discourse on language. In M. Foucault, The archeology of knowledge and the discourse on language (pp. 215-237). (A. M. Sheridan Smith, Trans.). New York: Pantheon Books.

Grosz, Elizabeth (1994). Volatile bodies: Toward a corporeal feminism. Bloomington and Indianapolis: Indiana University Press.

Grosz, Elizabeth (2010). The future of feminist theory: Dreams for new knowledges. Revista Eco-Pós, 13(3), 38-52. Retrieved from https://revistas.ufrj.br/index.php/eco_pos/article/view/848/788.

Haraway, Donna (1997). Modest_Witness@Second_Millennium. FemaleMan_Meets_OncoMouse. New York and London: Routledge. Haraway, Donna (1992). The promises of monsters: A Regenerative politics for inappropriate/d others. In L. Grosberg, C. Nelson, \& P. Treichler (Eds.), Cultural Studies (pp. 295-337). New York and London: Routledge.

Haraway, Donna (1988). Situated knowledges: The science question in feminism and the privilege of partial perspective. Feminist Studies, 14(3), 575599.

Irigaray, Luce (1993 [1985]). This sex which is not one. (C. Porter \& C. Burke, Trans.). Ithaca, New York: Cornell University Press.

Juelskjær, Malou \& Rogowska-Stangret, Monika (2017). A pace of our own? Becoming through speeds and slows - investigating living through temporal ontologies of the university. Feminist Encounters: A Journal of Critical Studies in Culture and Politics, 1(1). Retrieved from http://www.lectitopublishing.nl/viewpdf/WYQD6AIJ.

Kováts, Eszter \& Põim, Maari (Eds.). (2015). Gender as symbolic glue: The position and role of conservative and far right parties in the anti-gender mobilizations in Europe. Budapest: Foundation for European Progressive 
Studies, Friedrich-Ebert-Stiftung. Retrieved from https://library.fes.de/pdffiles/bueros/budapest/11382.pdf.

Kuhar, Roman \& Paternotte, David (Eds.). (2017). Anti-gender campaigns in Europe: Mobilizing against equality. London and Lanham: Rowman \& Littlefield International.

Lomax, Tamura (2015, May 30). Black women's lives don't matter in academia either, or why I quit spaces that don't value Black women's life and labor [Blog post]. Retrieved from

https://academicabolitionism.wordpress.com/2015/05/30/tamura-a-lomax-blackwomens-lives-dont-matter-in-academia-either/.

Lorde, Audre (1984). The transformation of silence into language and action. In A. Lorde, Sister Outsider: Essays and Speeches (pp. 41-44). Trumansburg, New York: Crossing Press.

Majewska, Ewa (2018). Weak resistance. Krisis. Journal of Contemporary Philosophy 2. Retrieved from https://krisis.eu/weak-resistance/.

Malabou, Catherine (2011). Changing difference: The feminine and the question of philosophy. (C. Shread, Trans.). Cambridge: Polity Press.

Maldonado, Marta, María \& Guenther, Katja M. (Eds.). (2017) Critical feminist exits, re-routings, and institutional betrayals in academia. Special issue of Feminist Formations [Call for papers]. Retrieved from https://networks.hnet.org/node/24029/discussions/981842/cfp-critical-feminist-exits-re-routingsand-institutional.

Massumi, Brian (2014). What animals teach us about politics. Durham and London: Duke University Press.

Petõ, Andrea (2018, September 24). Attack on freedom of education in Hungary: The case of gender studies [Blog post]. Retrieved from http://blogs.Ise.ac.uk/gender/2018/09/24/attack-on-freedom-of-education-inhungary-the-case-of-gender-studies/. 
Romero-Hall, Enilda; Aldemir, Tugce; Colorado-Resa, Jozenia; Dickson-Deane, Camille; Watson, Ginger, S., \& Sadaf, Ayesha (2018). Undisclosed stories of instructional design female scholars in academia. Women's Studies International Forum, 71, November, 19-28. Retrieved from https://www.sciencedirect.com/science/article/abs/pii/S0277539518302231?via\%3 Dihub.

Rogowska-Stangret, Monika \& Cielemęcka, Olga (2015, October 5). Vulnerable academic performances. Paper presented at the New Materialist Politics and Economies of Knowledge conference. Maribor, Slovenia.

Rogowska-Stangret, M. (2015). Of other spaces, of other times - towards new materialist politics of squatting. Avant. Trends in Interdisciplinary Studies, 6(1), 6580. Retrieved from http://avant.edu.pl/wp-content/uploads/Of-Other-Spaces.pdf.

Schrader, Astrid (2012). Haunted measurements: Demonic work and time in experimentation. Differences: A Journal of Feminist Cultural Studies, 23(3), 119_ 160. Retrieved from https://doi.org/10.1215/10407391-1892916.

Schuman, Rebecca (2013, October 24). "I quit academia," an important, growing subgenre of American essays. Slate. Retrieved from https://slate.com/culture/2013/10/quitting-academic-jobs-professor-zachary-ernstand-other-leaving-tenure-and-tenure-track-jobs-why.html.

Sedgwick, E. Kosofsky. (2003). Touching feeling: Affect, pedagogy, performativity. Durham and London: Duke University Press.

Standing, Guy (2011). The precariat: The new dangerous class. New York and London: Bloomsbury Academic.

Sullivan, Nikki (2015). The somatechnics of swallowing: Affective life in the neoliberal university. A keynote lecture presented at the Open Embodiments:

Bringing Somatechnics to Tucson, The University of Arizona, USA. 
Tagore, Shaunga (2011). A Slam on feminism in academia: A poem. In J. Yee (Ed.), Feminism for real: Deconstructing the academic industrial complex of feminism (pp. 37-41). Ottawa: The Canadian Centre for Policy Alternatives.

Taylor, Yvette \& Lahad, Kinneret (Eds.). (2018). Feeling academic in the neoliberal university: Feminist flights, fights and failures. Cham, Switzerland: Palgrave Macmillan.

Tsing, Anna (2012). Unruly edges: Mushrooms as companion species.

Environmental Humanities, 1, 141-154. Retrieved from

https://environmentalhumanities.org/arch/vol1/EH1.9.pdf. 